This is a self-archived - parallel published version of this article in the publication archive of the University of Vaasa. It might differ from the original.

\title{
The Long-Term Effects of Self-Initiated Expatriation on the Future Careers of Assignees
}

Author(s): $\quad$ Mello, Rodrigo; Dickmann, Michael; Brewster, Chris; Suutari, Vesa

Title: $\quad$ The Long-Term Effects of Self-Initiated Expatriation on the Future Careers of Assignees

Year: $\quad 2021$

Version: Accepted manuscript

Copyright $\quad$ (C)2021 Taylor \& Francis. This is an Accepted Manuscript of a book chapter published by Routledge in Selfinitiated expatriates in context: recognizing space, time, and institutions on 2 October 2020, available online: https://doi.org/10.4324/9780429352690-8

Please cite the original version:

Mello, R., Dickmann, M., Brewster, C. \& Suutari, V. (2021). The LongTerm Effects of Self-Initiated Expatriation on the Future Careers of Assignees. In: Andresen, M., Brewster, C. \& Suutari, V. (eds.) Selfinitiated expatriates in context: recognizing space, time, and institutions, 91-109. https://doi.org/10.4324/9780429352690-8 


\section{The Long-Term Effects of Self-Initiated Expatriation on the Future Careers of Assignees}

\section{Rodrigo Mello, Michael Dickmann, Chris Brewster, Vesa Suutari}

The project has received funding from the European Union's Horizon 2020 research and innovation programme under the Marie Skłodowska-Curie grant agreement No 765355.

\section{Introduction}

Job-related international mobility shapes life-courses and impacts self-initiated expatriates' (SIEs') careers abroad and upon return to the home country and thereafter (Suutari et al., 2018). In this chapter we examine the evidence for the effect of expatriate experience on their careers and explore some of the factors that impact that.

While some SIEs repatriate to their home country, others relocate to another country or decide to localise and stay abroad (Suutari, Tornikoski, \& Mäkelä, 2012). The nature of SIEs' jobs, the nature of their employers and the context in which SIEs' work all impact the career options available to SIEs after the assignment, both at home and internationally (Mäkelä, Suutari, Brewster, Dickmann, \& Tornikoski, 2016). The added value of their international work experience will also differ according to individual factors such as the career stage in which it was gained (Schmid \& Wurster, 2017). Evaluations of career success may vary depending on the timing of the evaluation, influenced by the context and type of expatriate. As an outcome, the overall objective and subjective career success of different types of SIEs may be very varied.

Scholars studying repatriation have tended to focus on how easily an expatriate is, in the short term, integrated back into their home environment (Chiang, van Esch, Birtch, \& Shaffer, 2017). There is little research on the long-term effect of international experience. To assess that we may need to move away from the tendency to treat SIEs as a homogenous group, and return to the original findings of heterogeneity among SIEs (e.g. Suutari \& Brewster, 2000). For instance, whether SIEs find a job in an organisation before moving to the host country, or whether they are trailing partners that look for a job after their arrival in a new country (Peltokorpi, 2008), will be relevant to assessing the 
influence of the international experience on their careers (Suutari et al., 2018). Similarly, it could be expected that the impact of a single assignment will vary between, say, internationally experienced senior managers and young graduates taking their first job abroad.

In the first part of this chapter, we discuss some of the similarities and differences in the motivations to work abroad, the types of career, and the outcomes for assigned expatriates (AEs) and SIEs. The aim of this section is to explain how those differences are relevant for understanding the influence of long-term international experience on careers. In the second part of the chapter, we approach the diverse accounts of the effect of assignments on careers. There are studies pointing to negative outcomes (e.g. Begley, Collings, \& Scullion, 2008), some pointing to positive outcomes (e.g. Myers \& Pringle, 2005), and others suggesting that there are both career benefits and career downsides of international work experience (Andresen, 2018; Makkonen, 2015). We aim to understand the reasons for such diverse findings. Finally, we explore the contextual nature of career outcomes among SIEs, discussing and analysing long-term effects of international assignments on future careers of assignees where SIEs are specifically identified: Those by Andresen and Biemann (2013), Begley et al. (2008), O'Connor (2018) and Suutari et al. (2018). We argue that such varied findings are tightly connected to the time when the data were collected and the context from which the evidence is drawn. Such diversity of contexts may thus be one of the main reasons for the contradictory evidence we have in the field of self-initiated expatriation. We connect this diversity of contexts with the diversity of the SIE population (Suutari \& Brewster, 2000).

\section{Contrasting the Careers of AEs and SIEs}

Scholars define SIEs as individuals who initiate and usually finance their own expatriation to a country of their choice to pursue cultural, personal, and career development experiences (Harrison, Shaffer, \& Bhaskar-Shrinivas, 2004; Jokinen, Brewster, \& Suutari, 2008; Myers \& Pringle, 2005) often with no definite period in mind (Tharenou \& Caulfield, 2010). Whether this is good or bad for such an expatriate's future career is unclear.

Assigned expatriates' careers are linked to their employing organisation (in some way) but progress within their current employing organisation may be less important in SIEs' decision-making 
(Richardson, 2006; Suutari \& Brewster, 2000). SIEs tend to follow a career path with less organisational support, handling all the transfer complications themselves (Andresen \& Biemann, 2013). Given the stronger career- and work-related motivation of AEs and their higher average status and position, AEs gain more organisational and business knowledge through their foreign work (Dickmann et al., 2018; Shaffer, Kraimer, Chen, \& Bolino, 2012). Because of their social connections within the organisation, AEs are also more likely to build better business contacts both at the head office and at their local operating unit (Farh, Bartol, Shapiro, \& Shin, 2010) whereas SIEs, tending to stay abroad longer, find their social connections in the home country quickly become weaker (Mäkelä \& Suutari, 2013). For both groups, long-term careers will be dependent on time and context.

\section{Understanding the Long-Term Impact of International Experience on the Career Success of Expatriates}

Empirical studies of expatriates define career success as the accomplishment of desirable, positive psychological or work-related outcomes as a result of international experiences accumulated over time (Holtbrügge \& Ambrosius, 2015; Ng, Eby, Sorensen, \& Feldman, 2005; Suutari et al., 2018). In the careers' literature, objective career success is defined as factors directly observable by others and measurable in a standardised way, such as salary or promotions (Arthur, Khapova, \& Wilderom, 2005; Gunz \& Heslin, 2005). Subjective career success is defined as the focal actor's evaluation and experience of achieving career outcomes meaningful to them personally ( $\mathrm{Ng}$ et al., 2005; Seibert, 2006; Shockley, Ureksoy, Rodopman, Poteat, \& Dullaghan, 2016), typically measured as career satisfaction (Greenhaus, Parasuraman, \& Wormley, 1990; Seibert, Kraimer, Holtom, \& Pierotti, 2013) or perceived career success (Heslin, 2003; Turban \& Dougherty, 1994) and, more recently, as a multidimensional evaluation of career facets, such as growth and development, personal life, and authenticity (Shockley et al., 2016). 


\section{Time}

Time is ridiculously underexplored in expatriate studies generally (Hippler, Brewster, \& Haslberger, 2015) and is obviously crucial for assessments of career success. Regardless of whether the focus of the studies is on objective or subjective career success, evaluations of career success will vary depending on the timing of the evaluation. Repatriation studies generally explore short-term outcomes, whereas long-term effects are rarely studied, despite calls for such research (Feldman \& Ng, 2007; Shaffer et al., 2012). Many, particularly, although not only, SIEs stay abroad indefinitely rather than repatriate (Jokinen et al., 2008; Stahl \& Cerdin, 2004; Suutari et al., 2012). Whether a study collects data 'shortly after' the international experience (repatriation studies), or a 'long period after' expatriates' international assignment influences the results.

So, the matter of 'time' is relevant. Studies collecting data shortly after an international work experience can only estimate adjustment issues and immediate outcomes arising from the repatriation itself, ignoring the cumulative effects over time (Fuller, 2008). Further, career mobility is known, on average, to be unevenly distributed over an individual's timeline (Dustmann \& Pereira, 2005; Kovalenko \& Mortelmans, 2014; Lam, Ng, \& Feldman, 2012; Tolbert, 1982; Topel \& Ward, 1992). The few studies collecting data from expatriates a long period after their first international work experience (Suutari et al., 2018) reflect the reality of the international career environment that includes repatriates, many of whom may settle down in their home environment after a period of stress, people who do not repatriate, staying longer in the new country, and those who accept a job with another employer in their original host country or in another country or countries (Suutari et al., 2018).

One other personal aspect of time concerns the career stage of the expatriate (see Chapter 7). As a career is a lifetime process (Arthur, 2008; Arthur \& Rousseau, 1996; Hall, 2002), the life stage and role that individuals experience might influence their assessment of career outcomes. Being a worker is just one life role, in addition to others such as child, student, and parent. Lifespan theory directly addresses the fact that individuals play multiple roles in their lives and that these roles change over the course of time (Nagy, Froidevaux, \& Hirschi, 2019). 


\section{Context}

The issue of 'context' includes the industry and geographic location. Careers are always careers-in-context (Mayrhofer, Meyer, \& Steyrer, 2007) and thus understanding context is vital for fully understanding individuals' careers. First, the assessment of career success is closely related to the kind of work the expatriate undertakes. Whether studies measure internal or external aspects of career success, context matters: The electronics sector, teaching or famine relief, finance or marketing are very different and will have different measures of success. Second, career choices take place within the context of countries and societies, under local institutions such as the legal, economic, cultural, and social norms (Brewster, Mayrhofer, \& Farndale, 2018. Third, the historical period of assessment plays a substantial role, as the socio-economic context in which careers develop changes over time due to employment dynamics: Expansion of production brings new jobs, recessions lead to job losses (Kovalenko \& Mortelmans, 2014).

Hence, alongside, and with, the effects of time on the long-term career success of expatriates, the evolution of industries in different geographic areas and the diversity of technological change affect employment in the different phases of economic cycles (Layard, Nickell, \& Jackman, 1991), driving expatriates to face the employability dilemma and the balance of labour supply and demand within particular industry sectors or geographical areas (Makkonen, 2015). Time can also affect the national, organisational, and individual contexts. For instance, local employers in China, in what has been a rapidly developing labour market, are constantly looking for talent and are becoming attractive career options for Westerners (Makkonen, 2015). In contrast to multinational enterprises operating in China, which are typically focused on localisation (Hartmann, Feisel, \& Schober, 2010), local organisations can still provide career and employment opportunities that may outweigh those available in the West (Makkonen, 2016). This applies particularly to SIEs who can "self-initiate their international relocation, with the intentions of regular employment and temporary stay" (Cerdin \& Selmer, 2014, p. 1293). So, a short-term measurement range may bias understanding of mobility in any particular context or time, which supports the argument in favour of using data describing prolonged, if not complete, career periods (Kovalenko \& Mortelmans, 2014). 


\section{The Long-Term Effects on SIEs' Careers}

There are a few studies that have taken a long-term view of what happens after self-initiated expatriates' international experience.

Andresen and Biemann (2013) conducted an online survey of 202 German managers. The authors divide their sample into different career groupings ('early career', 'international organisational career', 'international boundaryless career', and 'transnational career'), even if some of these groups have very small numbers in them. Individuals within each group showed similar sequences and frequencies of organisational and international mobility over their work life. The number of AEs in this sample is high because this study focuses on international experiences within organisations in Germany. However, out of the total number of career moves that respondents experienced, a quarter occurred as SIEs. Most SIEs' experiences occurred in the career group 'international boundaryless career'.

The two classes that are of central relevance are 'international organisational career' and 'international boundaryless career' as they contain individuals with multiple international career steps over their work lives that have a comparable length. These two classes had a global career either mainly within the same organisation ('international organisational career' typically as AEs) or by also changing employers ('international boundaryless career' mostly as SIE and some as AE).

'International organisational career' and 'international boundaryless career' differ sharply and significantly in terms of objective career success (OCS). The former group represented mostly by AEs indicated much higher OCS than the latter group represented by SIEs. As AEs typically had all their international moves within the organisation, it seems that going abroad as an SIE comes at a (financial) cost. However, although 'international boundaryless career' (SIEs) 'suffered' in terms of OCS (worse salary development), they were equally satisfied in terms of subjective career success (or even slightly higher) as 'international organisational career'. It is not all about money! This is very much in line with the multiple studies that show that SIEs are not all career-driven, but also pursue private motives and might draw their career satisfaction from other factors than money and promotions. 
Begley et al. (2008) studied the experiences of Irish SIEs repatriating to the Republic of Ireland. The timing and the overall context are again important. The research was done before the economic crisis in Ireland and thus the authors discuss the Irish context as one in which there was still impressive economic growth ('the Celtic Tiger'). Ireland was reported to have reversed centuries of emigration and become a country of immigration, due to a shortage of skilled labour. In such a situation, one could expect that the job market would be good for Irish repatriates with international experience.

The researchers assigned repatriates into three groups on the basis of how long they had been back home: $1-5$ years $(n=10), 5-10$ years $(n=6)$, and less than a year $(n=2)$. The study has some clear limitations but because there are very few studies analysing long-term career impacts and given the fact that some expatriates were interviewed up to 10 years after their assignment, we include it here.

Despite arriving at a time of labour shortage in Ireland, the experiences of repatriates were quite negative, often leading to dissatisfaction and poor labour market re-integration. The repatriates had to struggle to get employers to recognise their experience, and some of them felt that international experience was detrimental to their job search, minimising their international experience in their CVs. One was advised by a recruitment agency not to mention her extensive international job experience but to say that she had been a housewife abroad. Despite such challenges, repatriates did find jobs, often, however, at positions substantially lower than those they had abroad. Some of the repatriates struggled with the costs of moving back, combined with lengthy job search processes, and with related uncertainty, forcing quick acceptance of lower-level jobs. Where career success was better, often this was because the employer wanted to send them abroad again; not an idea attractive to repatriates who wanted to return to Ireland.

All in all, the findings of this repatriation study were mainly negative in career success terms. Despite good timing in repatriating to Ireland at a time of skill shortages, the respondents felt that their international experience was not much valued, whereas their lack of recent experience is Ireland was clearly limiting their employment opportunities. The timing made a difference: More challenges were faced immediately on return, whereas after a while the situation tended to improve. This was 
connected with the need to indicate that, as previously internationally mobile employees, they were committed to staying in Ireland longer term.

O'Connor (2018), in the same context, studied SIEs in Ireland (he called them 'skilled migrants' but they fulfil the definition of self-initiated expatriates offered by Cerdin and Selmer (2014). This study was focused on SIEs who moved from the ex-Communist bloc countries that had recently joined the EU to Ireland. Accession to the EU allows any individual in any member state freedoms to live and to work in any other EU state without any further clearance. Ireland had a significant labour shortage at the time and as a result, by 2012 , over $7 \%$ of the total Irish workforce consisted of citizens of these EU states.

Most of these SIEs had undertaken little preparation prior to moving to Ireland and, because they anticipated a short stay in the country, had not considered long-term career development. Few of the new arrivals had a job lined up when they moved to Ireland, although a minority had job interviews arranged on their behalf by their friends and relatives already in the country. As a result, their careers in Ireland typically involved two stages. Initially, they tended to accept the first job they were offered, whatever it was, as a way of funding themselves and establishing themselves in the country. After getting that start, they then tried to find better options and, indeed, most of them succeeded in finding better jobs later. A few, however, felt that they were 'stuck' in their entry-level jobs and found it difficult to move beyond them.

After a few years in Ireland, these SIEs started to realise that they were unlikely to move back to their home country anytime soon. Salaries, living and working conditions and general standards of living, and job security in the thriving Irish economy, were much better than they would be likely to experience back home. Thus, their planned 'expatriation' period abroad started to move towards consideration of a longer-term or even permanent stay abroad: These SIEs started to morph from their original SIE status towards (albeit unplanned) migrant status (McNulty \& Brewster, 2019). During the research, the interviewees had been living in Ireland for 6-8 years and had changed their plan to 'stay', at least for the immediate future. As time went by, many of them started to find better jobs in Ireland, perhaps after validation of their home country qualifications by taking extra classes and examinations. In addition, some of them created new careers in new professions. There was, however, 
also a smaller third group of people who never succeeded in getting better jobs than those they found at their entry stage to Ireland.

Considering their long-term careers, O'Connor found that the way respondents view their success had changed. While their objective career success may not always have been so great, they were, overall, happy with their life situation since they had adopted a 'working to live' career attitude. Such subjective career motivation explained the almost voluntary underemployment and the acceptance of lower career success in terms of external elements such as career advancement.

These results clearly reflect the importance of context and timing in expatriation. Without the opening of the job market that occurred as a result of the combination of their home countries joining the European Union, they would not have been in Ireland. The continuing employment opportunities and higher standard of living in Ireland during the following years, and the failure of their home countries to develop economically as fast as some had predicted, provided incentives to remain in the host country. Their adjustment to the new host country (Haslberger, Brewster, \& Hippler, 2014) followed a perhaps typical pattern, emphasising again the importance of time in assessing adjustment (Hippler et al., 2015). Early in their time in Ireland things were not so good for these SIEs. They were working in jobs that underutilised their skills and qualifications and they were living in temporary accommodation. As time went on most of them found jobs that were a better match for their skills and found permanent accommodation. Alongside these developments their expectations, ambitions and career objectives changed and many of them transitioned from SIEs to immigrants.

Suutari et al. (2018) took an even longer-term perspective. They studied the long-term career impact of international work among Finnish expatriates involving both assigned expatriates and SIEs, using an internet survey of Finnish business graduates with a university master's degree or higher who belong to the Finnish Association of Business School Graduates. That union was able to identify and follow up individuals who were working abroad in 2004 and a follow-up questionnaire was then sent to them in 2012 , i.e. eight years later.

The authors point out that career success might be perceived differently depending on when the evaluation is made. As we have seen, the best available evidence of what happens to people after their expatriation experience comes from repatriation studies (Benson \& Pattie, 2008; Lazarova \& Caligiuri, 2002; Suutari \& Brewster, 2003). But, as noted previously, these are, almost by definition, 
largely restricted to assigned expatriates and only explore the outcomes over a relatively short time period after return. In contrast, there has been very little research that takes a long-term perspective. In the Suutari et al. (2018) study reliable, representative, data was collected several years after the expatriate experience. Our understanding is enhanced by such evidence: from such a more typical expatriate population (Kraimer, Shaffer, \& Bolino, 2009), including those who have stayed abroad rather than repatriating (Suutari et al., 2012), those who work in other types of organisations than multinational corporations (e.g. in the European Commission and in other public/third sector organisations, or in small and medium-sized enterprises), and in particular, those who are selfinitiated expatriates (Al Ariss \& Crowley-Henry, 2013).

The results of the Suutari et al. (2018) study indicate that when we have better matched samples of AEs and SIEs (they had similar levels and types of education), the career success of both groups of assignees is very similar in the long term. The two different categories of assignees had equal numbers of promotions after the assignment. The only identified difference was that AEs changed their job due to job offers more often (75\%) than SIEs (50\%). Furthermore, the analysis indicates that from these offers, $72 \%$ of AE job offers were internal compared to $47 \%$ for SIEs. From another angle, SIEs tend to more actively look for and change jobs on their own initiative - as they had done when leaving to go abroad. Concomitantly, a larger proportion of AEs, compared to SIEs, in this sample, had repatriated back to Finland.

With regard to subjective career success, the findings indicate that the type of assignment (AEs/SIEs) made little difference to the expatriates' experiences of the impact of international work on subjective career success. No difference was found in the perceived external or internal marketability of respondents_-neither in home job markets nor internationally (cf. Mäkelä et al., 2016). There was a similar result with regard to career satisfaction: Both types of assignees were as satisfied with their careers.

Without a control group of those without international experience, it cannot be concluded whether the objective career success would have been better, equal, or worse without such experience. However, in a further analysis of the experiences of these SIEs, Brewster, Mäkelä, and Suutari (2018) report that SIEs had positive views on this: $70 \%$ agreed with the statement that work experience abroad had helped them to get another good job and $83 \%$ agreed that such experience had overall 
impacted positively on their career success and career progress. An even larger proportion (91\%) felt that international work had developed important skills that have been useful in their later career. These positive observations were also reflected in overall career satisfaction, which was high: $52 \%$ were very satisfied with their overall career success whereas $31 \%$ were satisfied.

The fact that this evidence was collected from Finnish expatriates (context) might have made a difference: As a small economy, Finland is very dependent on international trade. One outcome is that international experience may be more valued than it is in countries with larger home markets in proportion to their international trade. The evidence comes from a country with a relatively highly educated, multilingual workforce (OECD, 2019) with an international orientation. There is at least a possibility therefore that Finns are more likely to be SIEs than some other nationalities and, perhaps, more successful as expatriates. The sample of expatriates represented university-level-educated business professionals who on average have good starting points for making successful careers. Whether the findings would be different in other educational fields or among those with lower levels of education would require further research.

\section{Discussion and Conclusions}

This chapter set out to explore the long-term career effects of self-initiated expatriates. While the majority of global mobility research has concentrated on assigned expatriates, our chapter has made it clear that even where there is work that concentrates on SIEs there are large gaps. Over the long term, SIEs, like AEs, believe their international marketability has increased and is higher than their home country marketability, particularly so for SIEs (Suutari et al., 2018). There seems to be a beginning of evidence that expatriation, whether or not as an SIE, is good for your career.

However, the long-term careers and expatriation research is relatively underdeveloped. From this 'thin' evidence base we are developing an overview of the complex context that SIEs - whether they have repatriated or still work abroad - are embedded in and which has a strong impact on their long-term career success. This is, inevitably, a framework that needs to take account of both structure and agency in careers (Gunz \& Peiperl, 2007). We suggest some future steps next. 


\section{Research on Expatriate Career Success Needs to Explore Temporal Elements}

Previously, we have argued that time matters in research analysing career effects after international experience. Most existing research has concentrated on what happens at the point of return home or shortly afterwards. This has led to studies exploring the host context in terms of data such as employment patterns or more meso-level elements such as the relative attractiveness of repatriates to employers (Andresen, 2018 for SIEs; Lazarova \& Cerdin, 2007 for AEs). In addition, the readjustment of SIEs and AEs has also been a focus of interest (Guo, Porschitz, \& Alves, 2013; McDonnell \& Scullion, 2013). However, things may change over time - for instance in terms of intellectual, emotional, and behavioural (re-)adjustment (Hippler et al., 2015). In addition, we have seen that the marketability of repatriates may be affected by their first job in the country of return (Begley et al., 2008) or the ways that repatriates may acquire and combine international and locally acquired knowledge, skills, or networks in order to further their subjective and objective careers. Given the severe paucity of long-term repatriation research (especially for SIEs but also for AEs) that has been outlined previously, it is clearly important to incorporate (long-term) temporal elements into global mobility research (Suutari et al., 2018).

\section{Research on Expatriate Career Success Needs to Integrate the Micro Perspectives of Individual Context}

A large part of the SIE literature has concentrated on SIEs themselves (and their families) but there has been little attention to time. There is evidence that international work experience is more impactful at earlier rather than at later career stages (Hamori \& Koyuncu, 2011; Schmid \& Wurster, 2017). The length of the work-related stay abroad may also have an impact because the longer one stays abroad, the more difficult the integration back to home country job markets will be (Hamori \& Koyuncu, 2011; Schmid \& Wurster, 2017): and SIEs stay longer abroad (Andresen \& Biemann, 2013; Shaffer et al., 2012). In line with this, having multiple international assignments may restrict access to top jobs due to long-term absence from the home country and/or the HQs of MNCs and the loss or weakening of critical networks (Schmid \& Wurster, 2017). 
Family is important (Al Ariss \& Özbilgin, 2010; Haslberger \& Brewster, 2008; Tharenou \& Caulfield, 2010) and it appears that it would be useful to explore factors such as work-life balance, emotional or health spill-over effects in more detail (Mäkelä \& Suutari, 2013; Mäkelä \& Suutari, 2015).

In addition, factoring in the educational level of SIEs and their career capital has an impact on their work experiences and career journeys (Dickmann et al., 2018; Inkson \& Arthur, 2001). The long-term career impact of self-initiated expatriation is influenced by the SIEs' educational level (O'Connor, 2018) and the jobs they undertake abroad and upon return (Begley et al., 2008). Their subjective assessment of career success is also likely to depend on their original motivations to work abroad (Doherty, Dickmann, \& Mills, 2011; Hippler, 2009).

\section{Research on Expatriate Career Success Needs to Investigate the Meso Level of Organisational Context}

While the expatriation literature has mostly concentrated on the micro level, as described previously, the organisational context into which self-initiated repatriates are embedded is crucial to grasping their career experiences (Andresen \& Walther, 2013). Begley et al. (2008) have indicated that the assessment of foreign experiences by local employers will be important. In addition, the international strategies, structures, policies, and practices of firms (Farndale \& Paauwe, 2007; Scullion \& Collings, 2011) will influence how attractive self-initiated repatriates are to these organisations. Crucially, this will also shape career opportunities for those with international experience in these firms. The international business literature has for decades explored the myriad of elements - including resource distributions, operating models, senior management mindsets, local embeddedness of foreign units, international sales and growth patterns etc. - that shape how 'transnational' an organisation is (Bartlett \& Ghoshal, 2002). The more transnational, the higher the chance that foreign experience and insights are valued and, hence, the possibilities for increased subjective career success of international workers, including self-initiated repatriates. Overall, exploring the organisational context that SIEs are facing after return is essential to understanding long-term career patterns. 


\section{Research on SIE (and AE) Career Success Needs to Understand the Impact of the Macro Perspective of Country Context}

Two recent books on macro talent management in emerging, emergent, and developing markets (Vaiman, Sparrow, Schuler, \& Collings, 2019a, 2019b) have made the case for looking at country context in relation to global mobility. Taking an institutional approach, the diverse political, economic, socio-cultural, technical and legal aspects that impact working in specific countries matter. For instance, Brexit is seen to have potentially strong political and legal implications for EU citizens in the United Kingdom (Hantrais, 2018) which, in turn, may affect the attractiveness of the UK as a destination country (Montesi, Pagliacci, Slupinska, Boldureanu, \& Boldureanu, 2018). The economic situation - especially unemployment rates and industry trends - is also seen as influencing location choice for expatriates. Technical or innovation leadership in certain industries (e.g. finance, telecommunications) as well as socio-cultural factors have been found to make certain countries and even specific locations within these countries particularly attractive for some expatriates (Dickmann \& Mills, 2009). In turn, a hostile environment can diminish the attractiveness of host locations and lead to a range of negative outcomes, including stress or withdrawal cognitions (Bader \& Berg, 2013; Bader, Reade, \& Froese, 2019). Gannon and Paraskevas (2017) and Harvey, Dabic, Kiessling, Maley, and Moeller (2017) incorporate the macro perspective of hostile environments with the meso-level perspective of how organisations could manage these situations.

Overall, we advance the argument that global mobility research, in general, and the assessment of (long-term) career success of self-initiated (and assigned) expatriates, in particular, would benefit from a more holistic approach. Figure 6.1 depicts the individual-, organisational-, and country-level contexts that will impact so many expatriation attitudes, behaviours, emotions, and outcomes. Clearly, these levels are interrelated as effects on one will often have an impact on another level. For instance, expatriates who strengthen their marketability and career capital have more chances to move outside their current organisation to another employer (Lazarova \& Cerdin, 2007). Incorporating temporal perspectives (including those of career stages) will add to the validity and 
quality of research that seeks to understand expatriation in more depth, be it career effects or other phenomena.

Figure 6.1 An overview of SIE context and temporal elements impacting on career

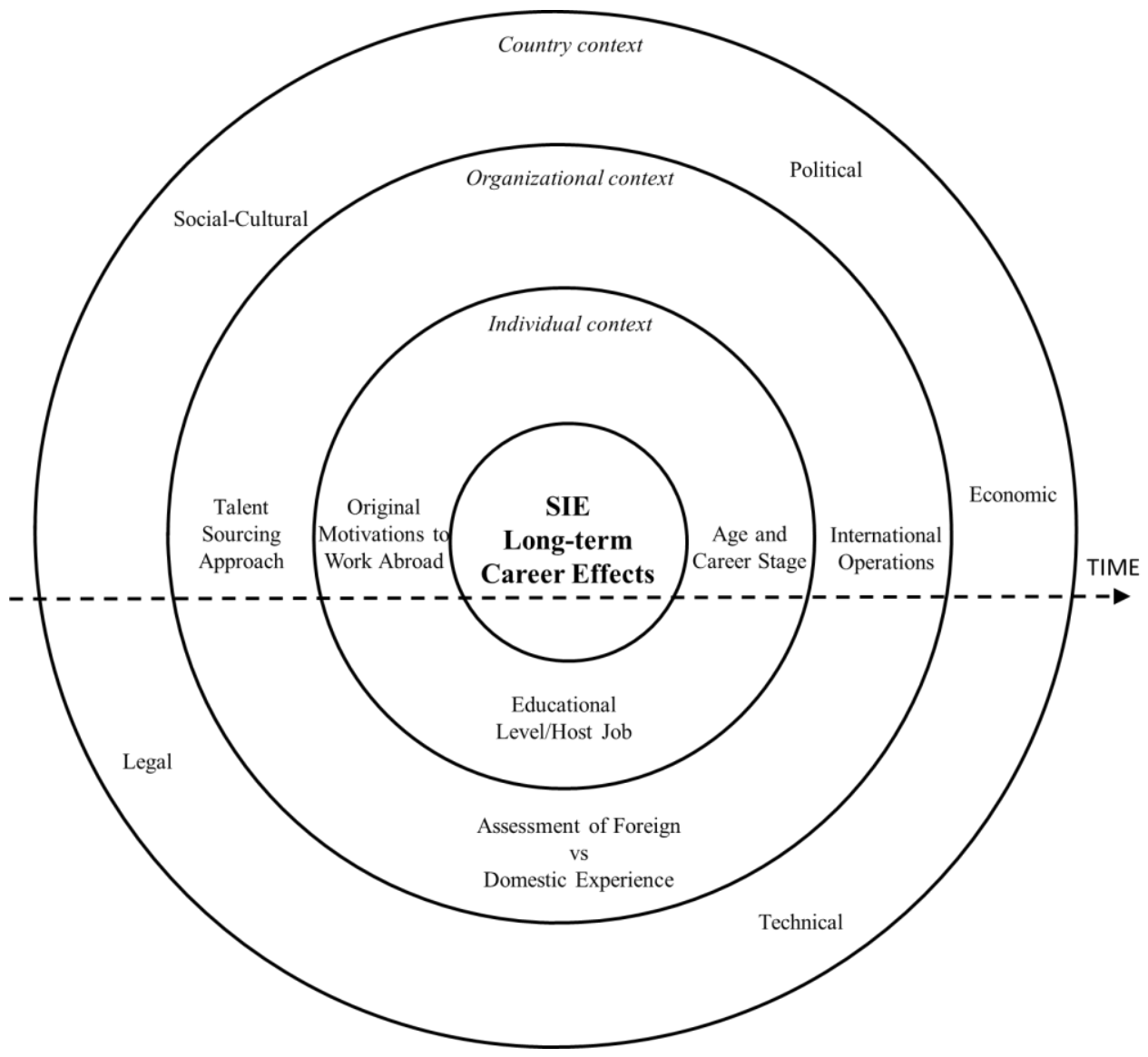

\section{Upping the Game: Comparative Career (Success) Research Across Countries and Regions (Contrasting Domestic, AE and SIE Groups)}

Our insights into the long-term career effects of international experience for SIEs are at a very early stage. Research has been conducted in very few countries; and we call for more research into exploring diverse contexts and how these shape the career journeys and outcomes of SIEs. After all, our broad framework does indicate that these journeys would be different not just because individuals differ in their agency and personal attributes but also because their context is radically different. Exploring long-term career patterns of globally mobile workers could lead to an extension of the expatriation literature by adding a stronger comparative element. Akin to how CRANET has 
strengthened our insights into comparative HRM (Brewster et al., 2018) and the 5C Network is establishing comparative career insights (Mayrhofer et al., 2016), this might lead to a more holistic and context-sensitive assessment of expatriation and careers.

\section{References}

Al Ariss, A., \& Crowley-Henry, M. (2013). Self-initiated expatriation and migration in the management literature: Present theorizations and future research directions. Career Development International, 18(1), 78-96. https://doi.org/10.1108/13620431311305962

Al Ariss, A., \& Özbilgin, M. (2010). Understanding self-initiated expatriates: Career experiences of Lebanese self-initiated expatriates in France. Thunderbird International Business Review, 52(4), 275-285. https://doi.org/10.1002/tie

Andresen, M. (2018). When at home, do as they do at home? Valuation of self-initiated repatriates' competences in French and German management career structures. The International Journal of Human Resource Management, 1-33.

https://doi.org/10.1080/09585192.2018.1511612

Andresen, M., \& Biemann, T. (2013). A taxonomy of global careers: Identifying different types of international managers. The International Journal of Human Resource Management, 24(3), 533-557. https://doi.org/10.1080/09585192.2012.697476

Andresen, M., \& Walther, M. (2013). Self-initiated repatriation at the interplay between field, capital, and habitus: An analysis based on Bourdieu's theory of practice. In M. Andresen, A. Al Ariss, \& M. Walther (Eds.), Self-initiated expatriation: Individual, organizational, and national perspectives (pp. 160-180). London: Routledge.

Arthur, M. B. (2008). Examining contemporary careers: A call for interdisciplinary enquiry. Human Relations, 61(2), 163-183. https://doi.org/10.1177/0018726707087783

Arthur, M. B., Khapova, S. N., \& Wilderom, C. P. M. (2005). Career success in a boundaryless career world. Journal of Organizational Behavior, 26(2), 177-202. https://doi.org/10.1002/job.290 
Arthur, M. B., \& Rousseau, D. M. (1996). The boundaryless career: A new employment principle for a new organisational era. New York: Oxford University Press.

Bader, A. K., Reade, C., \& Froese, F. J. (2019). Terrorism and expatriate withdrawal cognitions: The differential role of perceived work and non-work constraints. The International Journal of Human Resource Management, 30(11), 1769-1793. https://doi.org/10.1080/09585192.2016.1233448

Bader, B., \& Berg, N. (2013). An empirical investigation of terrorism-induced stress on expatriate attitudes and performance. Journal of International Management, 19(2), 163-175. https://doi.org/10.1016/j.intman.2013.01.003

Bartlett, C. A., \& Ghoshal, S. (2002). Managing across borders: The transnational solution. Cambridge, MA: Harvard Business Press.

Begley, A., Collings, D. G., \& Scullion, H. (2008). The cross-cultural adjustment experiences of self-initiated repatriates to the Republic of Ireland labour market. Employee Relations, 30(3), 264-282. https://doi.org/10.1108/01425450810866532

Benson, G. S., \& Pattie, M. (2008). Is expatriation good for my career? The impact of expatriate assignments on perceived and actual career outcomes. The International Journal of Human Resource Management, 19(9), 1636-1653. https://doi.org/10.1080/09585190802295058

Brewster, C., Mäkelä, L., \& Suutari, V. (2018). Career of highly educated self-initiated expatriates: Observations from studies among Finnish business professionals. In D. Habti \& M. Elo (Eds.), Global mobility of highly skilled people-Multidisciplinary perspectives on selfinitiated expatriation (pp 41-56). Cham: Springer. https://doi.org/10.1007/978-3-31995056-3_2

Brewster, C., Mayrhofer, W., \& Farndale, E. (2018). Handbook of research on comparative human resource management. Chichester: Edward Elgar Publishing.

Cerdin, J. L., \& Selmer, J. (2014). Who is a self-initiated expatriate? Towards conceptual clarity of a common notion. The International Journal of Human Resource Management, 25(9), 1281-1301. https://doi.org/10.1080/09585192.2013.863793 
Chiang, F. F. T., van Esch, E., Birtch, T. A., \& Shaffer, M. A. (2017). Repatriation: What do we know and where do we go from here? The International Journal of Human Resource Management, 29(1), 188-216. https://doi.org/10.1080/09585192.2017.1380065

Dickmann, M., \& Mills, T. (2009). The importance of intelligent career and location considerations: Exploring the decision to go to London. Personnel Review, 39(1), 116-134. https://doi.org/10.1108/00483481011007896

Dickmann, M., Suutari, V., Brewster, C., Mäkelä, L., Tanskanen, J., \& Tornikoski, C. (2018). The career competencies of self-initiated and assigned expatriates: Assessing the development of career capital over time. The International Journal of Human Resource Management, 29(16), 2353-2371. https://doi.org/10.1080/09585192.2016.1172657

Doherty, N., Dickmann, M., \& Mills, T. (2011). Exploring the motives of company-backed and self-initiated expatriates. The International Journal of Human Resource Management, 22(3), 595-611. https://doi.org/10.1080/09585192.2011.543637

Dustmann, C., \& Pereira, S. C. (2005). Wage growth and job mobility in the U.K. and Germany (IZA Discussion Paper No. 1586). Institute for the Study of Labor (IZA). Retrieved October 21, 2018 from http://ideas.repec.org/p/iza/izadps/dp1586.html

Farh, C. I., Bartol, K., Shapiro, D. L., \& Shin, J. (2010). Networking abroad: A process model of how expatriates form support ties to facilitate adjustment. Academy of Management Review, 35(3), 434-454. https://doi.org/10.5465/amr.35.3.zok434

Farndale, E., \& Paauwe, J. (2007). Uncovering competitive and institutional drivers of HRM practices in multinational corporations. Human Resource Management Journal, 17(4), 355375. https://doi.org/10.1111/j.1748-8583.2007.00050.x

Feldman, D. C., \& Ng, T. W. H. (2007). Careers: Mobility, embeddedness, and success. Journal of Management, 33(3), 350-377. https://doi.org/10.1177/0149206307300815

Fuller, S. (2008). Job mobility and wage trajectories for men and women in the United States. American Sociological Review, 73(1), 158-183. https://doi.org/10.1177/000312240807300108 
Gannon, J., \& Paraskevas, A. (2017). In the line of fire: Managing expatriates in hostile environments. The International Journal of Human Resource Management, 30(11), 17371768. https://doi.org/10.1080/09585192.2017.1322122

Greenhaus, J. H., Parasuraman, S., \& Wormley, W. M. (1990). Effects of race on organisational experiences, job performance evaluations, and career outcomes. Academy of Management Journal, 33(1), 64-86. https://doi.org/10.2307/256352

Gunz, H. P., \& Heslin, P. A. (2005). Reconceptualizing career success. Journal of Organizational Behavior, 26(2), 105-111. https://doi.org/10.1002/job.300

Gunz, H. P., \& Peiperl, M. (2007). Introduction. In H. Gunz \& M. Peiperl (Eds.), Handbook of career studies (pp. 1-10). Thousand Oaks, CA: Sage Publications.

Guo, C., Porschitz, E. T., \& Alves, J. (2013). Exploring career agency during self-initiated repatriation: A study of Chinese sea turtles. Career Development International, 18(1), 34 55. https://doi.org/10.1108/1362043131130

Hall, D. T. (2002). Protean careers in and out of organisations. Thousand Oaks, CA: Sage. https://doi.org/10.4135/9781452231174.n2

Hamori, M., \& Koyuncu, B. (2011). Career advancement in large organisations in Europe and the United States: Do international assignments add value? The International Journal of Human Resource Management, 22(4), 843-862. https://doi.org/10.1080/09585192.2011.555128

Hantrais, L. (2018). How will Brexit affect the social security rights of EU migrants in the UK, and how the social protection of EU staff? British Politics and Policy at LSE. Retreived October 25, 2018 from https://blogs.lse.ac.uk/politicsandpolicy/how-will-brexit-affect-the-socialsecurity-rights-of-eu-migrants-and-how-the-social-protection-of-eu-staff/

Harrison, D. A., Shaffer, M. A., \& Bhaskar-Shrinivas, P. (2004). Going places: Roads more and less traveled in research on expatriate experiences. Research in Personnel and Human Resources Management, 23(2), 199-247. https://doi.org/10.1016/S0742-7301(04)23005-5 Hartmann, E., Feisel, E., \& Schober, H. (2010). Talent management of Western MNCs in China: Balancing global integration and local responsiveness. Journal of World Business, 45(2), 169-178. https://doi.org/10.1016/j.jwb.2009.09.013 
Harvey, M., Dabic, M., Kiessling, T., Maley, J., \& Moeller, M. (2017). Engaging in duty of care:

Towards a terrorism preparedness plan. The International Journal of Human Resource Management, 30(11), 1683-1708. https://doi.org/10.1080/09585192.2017.1298651

Haslberger, A., \& Brewster, C. (2008). The expatriate family: An international perspective. Journal of Managerial Psychology, 23(3), 324-346. https://doi.org/10.1108/02683940810861400

Haslberger, A., Brewster, C., \& Hippler, T. (2014). Managing performance abroad: A new model for understanding expatriate adjustment. London: Routledge.

Heslin, P. A. (2003). Self- and other-referent criteria of success. Journal of Career Assessment, 11(3), 262-286. https://doi.org/10.1177/1069072703254500

Hippler, T. (2009). Why do they go? Empirical evidence of employees' motives for seeking or accepting relocation. The International Journal of Human Resource Management, 20(6), 1381-1401. https://doi.org/10.1080/09585190902909889

Hippler, T., Brewster, C., \& Haslberger, A. (2015). The elephant in the room: The role of time in expatriate adjustment. The International Journal of Human Resource Management, 26(15), 1920-1935. https://doi.org/10.1080/09585192.2015.1041762

Holtbrügge, D., \& Ambrosius, J. (2015). Mentoring, skill development, and career success of foreign expatriates. Human Resource Development International, 18(3), 278-294. https://doi.org/10.1080/13678868.2015.1071989

Inkson, K., \& Arthur, M. B. (2001). How to be a successful career capitalist. Organisational Dynamics, 30(1), 48-61. https://doi.org/10.12691/jbms-1-4-4

Jokinen, T., Brewster, C., \& Suutari, V. (2008). Career capital during international work experiences: Contrasting self-initiated expatriates experiences and assigned expatriation. The International Journal of Human Resources Management, 19(6), 979-998. https://doi.org/10.1080/09585190802051279

Kovalenko, M., \& Mortelmans, D. (2014). Does career type matter? Outcomes in traditional and transitional career patterns. Journal of Vocational Behavior, 85(2), 238-249. doi:

Kraimer, M. L., Shaffer, M. A., \& Bolino, M. C. (2009). The influence of expatriate and repatriate experiences on career advancement and repatriate retention. Human Resource Management, 48(1), 27-47. https://doi.org/10.1002/hrm 
Lam, S. S. K., Ng, T. W. H., \& Feldman, D. C. (2012). The relationship between external job mobility and salary attainment across career stages. Journal of Vocational Behavior, 80(1), 129-136. https://doi.org/10.1016/j.jvb.2011.05.002

Layard, R., Nickell, S., \& Jackman, R. (1991). Unemployment: Macroeconomic performance and the labour market. Oxford: Oxford University Press.

Lazarova, M. B., \& Caligiuri, P. (2002). Retaining repatriates: The role of organisational support practices. Journal of World Business, 36(4), 389-401. https://doi.org/10.1016/S10909516(01)00063-3

Lazarova, M. B., \& Cerdin, J. L. (2007). Revisiting repatriation concerns: Organisational support versus career and contextual influences. Journal of International Business Studies, 38(3), 404-429. https://doi.org/10.1057/palgrave.jibs.8400273

Mäkelä, L., \& Suutari, V. (2013). Work-life interface of self-initiated expatriates: Conflicts and enrichment. In V. Vaiman \& A. Haslberger (Eds.), Managing talent of self-initiated expatriates: A neglected source of the global talent flow. London: Palgrave Macmillan.

Mäkelä, L., \& Suutari, V. (2015). The work and personal life interface in the international career context: An introduction. In L. Mäkelä \& V. Suutari (Eds.), Work and family interface in international career context (pp. 1-10). Cham: Springer.

Mäkelä, L., Suutari, V., Brewster, C., Dickmann, M., \& Tornikoski, C. (2016). The impact of career capital on expatriates' marketability. Thunderbird International Business Review, 58(1), 2940. https://doi.org/10.1002/tie.21742

Makkonen, P. (2015). Perceived employability development of Western self-initiated expatriates in local organisations in China. Journal of Global Mobility, 3(4), 350-377. https://doi.org/10.1108/JGM-05-2015-0015

Makkonen, P. (2016). Career self-management behaviour of Western self-initiated expatriates in local organisations in China. The International Journal of Human Resource Management, 27(11), 1135-1157. https://doi.org/10.1080/09585192.2015.1061580

Mayrhofer, W., Briscoe, J. P., Hall, D. T. T., Dickmann, M., Dries, N., Dysvik, A., \& Unite, J. (2016). Career success across the globe. Organisational Dynamics, 45(3), 197-205. https://doi.org/10.1016/j.orgdyn.2016.07.005 
Mayrhofer, W., Meyer, M., \& Steyrer, J. (2007). Contextual issues in the study of careers. In H. P. Gunz \& M. Peiperl (Eds.), Handbook of career studies (pp. 215-240). London: Sage.

McDonnell, A., \& Scullion, H. (2013). Self-initiated expatriate's adjustment: A neglected terrain. In V. Vaiman \& A. Haslberger (Eds.), Talent management of self-initiated expatriates (pp. 136-155). London: Palgrave Macmillan.

McNulty, Y., \& Brewster, C. (2019). Working internationally: Expatriation, migration and other global work. Cheltenham: Edward Elgar.

Montesi, C., Pagliacci, M. G., Slupinska, M., Boldureanu, G., \& Boldureanu, D. (2018). In and out European Union. Widening, immigration, Brexit in the opinion of students. European Journal of Sustainable Development, 7(2), 141-164. https://doi.org/10.14207/ejsd.2018.v7n2p141.

Myers, B., \& Pringle, J. K. (2005). Self-initiated foreign experience as accelerated development: Influences of gender. Journal of World Business, 40(4), 421-431. https://doi.org/1010.1016/j.jwb.2005.08.009

Nagy, N., Froidevaux, A., \& Hirschi, A. (2019). Lifespan perspectives on careers and career development. In B. B. Baltes, C. W. Rudolph, \& H. Zacher (Eds.), Work across the lifespan (pp. 155-174). London: Elsevier.

Ng, T. W. H., Eby, L. T., Sorensen, K. L., \& Feldman, D. C. (2005). Predictors of objective and subjective career success: A meta-analysis. Personnel Psychology, 58(2), 367-408. https://doi.org/10.1111/j.1744-6570.2005.00515.x

O’Connor, E. (2018). Skilled migrants and international careers: A qualitative study and interpretation of the careers and perceived success of skilled migrant workers in Ireland (Doctoral Thesis). Maynooth University, Ireland.

OECD. (2019). Excellence and equity in education: The organisation for economic cooperation and development. Retrieved October 28, 2019 from www.oecd.org/publications/pisa-2015results-volume-i-9789264266490-en.htm

Peltokorpi, V. (2008). Cross-cultural adjustment of expatriates in Japan. The International Journal of Human Resource Management, 19(9), 1588-1606.

https://doi.org/10.1080/09585190802294903 
Richardson, J. (2006). Self-directed expatriation: Family matters. Personnel Review, 35(4), 469486. https://doi.org/10.1108/00483480610670616

Schmid, S., \& Wurster, D. J. (2017). International work experience: Is it really accelerating the way to the management board of MNCs? International Business Review, 26(5), 991-1008. https://doi.org/10.1016/j.ibusrev.2017.03.006

Scullion, H., \& Collings, D. (2011). Global talent management. London: Routledge.

Seibert, S. E. (2006). Career success. In J. H. Greenhaus \& G. A. Callanan (Eds.), Encyclopedia of career development (pp. 148-154). London: Sage.

Seibert, S. E., Kraimer, M. L., Holtom, B. C., \& Pierotti, A. J. (2013). Even the best laid plans sometimes go askew: Career self-management processes, career shocks, and the decision to pursue graduate education. Journal of Applied Psychology, 98(1), 169-182. https://doi.org/10.1037/a0030882

Shaffer, M. A., Kraimer, M. L., Chen, Y. P., \& Bolino, M. C. (2012). Choices, challenges, and career consequences of global work experiences: A review and future agenda. Journal of Management, 38(4), 1282-1327. https://doi.org/10.1177/0149206312441834

Shockley, K. M., Ureksoy, H., Rodopman, O. B., Poteat, L. F., \& Dullaghan, T. R. (2016). Development of a new scale to measure subjective career success: A mixed-methods study. Journal of Organisational Behavior, 37(1), 128-153. https://doi.org/10.1002/job.2046

Stahl, G., \& Cerdin, J.-L. (2004). Global careers in French and German multinational corporations. Journal of Management Development, 23(9), 885-902. https://doi.org/10.1108/02621710410558486

Suutari, V., \& Brewster, C. (2000). Making their own way: International experience through selfinitiated foreign assignments. Journal of World Business, 35(4), 417-436. https://doi.org/10.1016/S1090-9516(00)00046-8

Suutari, V., \& Brewster, C. (2003). Repatriation: Empirical evidence from a longitudinal study of careers and expectations among Finnish expatriates. The International Journal of Human Resource Management, 14(7), 1132-1151. https://doi.org/10.1080/0958519032000114200

Suutari, V., Brewster, C., Dickmann, M., Mäkelä, L., Tanskenan, J., \& Tornikoski, C. (2018). The effect of international work experience on the career success of expatriates: A comparison of 
assigned and self-initiated expatriates. Human Resource Management, 57(1), 37-54. https://doi.org/10.1002/hrm.21827

Suutari, V., Tornikoski, C., \& Mäkelä, L. (2012). Career decision making of global careerists. The International Journal of Human Resource Management, 23(15-16), 3455-3478. https://doi.org/10.1080/09585192.2011.639026

Tharenou, P., \& Caulfield, N. (2010). Will I stay or will I go? Explaining repatriation by selfinitiated expatriates. Academy of Management Journal, 53(5), 1009-1028. https://doi.org/10.5465/AMJ.2010.54533183

Tolbert, C. (1982). Industrial segmentation and men's career mobility. American Sociological Review, 47(4), 457-477. https://doi.org/10.2307/2095192

Topel, R. H., \& Ward, M. P. (1992). Job mobility and the careers of young men. Quarterly Journal of Economics, 107(2), 439-479. https://doi.org/10.2307/2118478

Turban, D., \& Dougherty, T. (1994). Role of protégé personality in receipt of mentoring and career success. Academy of Management Journal, 37(3), 688-702. https://doi.org/10.5465/256706

Vaiman, V., Sparrow, P., Randall Schuler, R., \& Collings, D. G. (2019a). Macro talent management in emerging and emergent markets: A global perspective on management talent in developed markets. London: Routledge.

Vaiman, V., Sparrow, P., Randall Schuler, R., \& Collings, D. G. (2019b). Macro talent management in emerging and emergent markets: A global perspective on management talent in emerging and emergent markets. London: Routledge. 